\section{Employee's Performance in a Commission for General Election of Banten Province, an Evidence From Indonesia}

\author{
Syaeful Bahri \\ Graduate Program of Human Resources Management, \\ Universitas Negeri Jakarta, Jl.Rawamangun Muka, Jakarta Timur 13220, Indonesia. \\ Email: syaefulbahri_im11s3@mahasiswa.unj.ac.id;syaefulbhr@yahoo.com
}

Ma'ruf Akbar

Lecturer of Human Resources Management,

Universitas Negeri Jakarta, Jl.Rawamangun Muka, Jakarta Timur 13220, Indonesia.

Email: maruf.akbar@unj.ac.id

Billy Tunas

Lecturer of Human Resources Management,

Universitas Negeri Jakarta, Jl.Rawamangun Muka, Jakarta Timur 13220, Indonesia.

Email: tunas.billy@gmail.com

Sukemi Kadiman (Corresponding author)

Lecturer of Human Resources Management,

Sekolah Tinggi Ilmu Ekonomi, Jl.Raya Bekasi, Jakarta Timur 13950, Indonesia.

Email: massukemi@gmail.com; sukemi@ caturkhitapersada.com

Received: June 11, 2019 Accepted: July 11, 2019 Online published: July 22, 2019

doi:10.5296/ijhrs.v9i3.15128 URL: https://doi.org/10.5296/ijhrs.v9i3.15128 


\section{Abstract}

The importance of employee performance research in a Commission for General Election of Banten Province-Indonesia as the main problem in this research based on empirical data that we obtained from the General Election Commission in Banten Provincial Office, data shows that employee performance is not optimal yet. The state of the art of this research can be stated that this study supports the results of other studies conducted previously on the Effect of Leadership Integrity, Team Cohesiveness and Task Commitment on Employee Performance. The purpose of this study is to examine the Effect of Leadership Integrity, Team Cohesiveness and Task Commitment on Employee Performance of the General Election Commission in Banten Province. Quantitative research has been applied to this study, the respondents were employees of the Banten Provincial Election Commission. The random sampling technique was selected. The primary data, questionnaires, and tests were analyzed by path analysis. The research found that there is the Influence of Leadership Integrity, Team Cohesiveness and Task Commitment on the Employee Performance of the General Election Commission in Banten Province, Indonesia. Some recommendations are given a consideration factor in other similar organizations.

Keywords: leadership integrity, team cohesiveness, task commitment, employee performance, general election commission

\section{Introduction}

The General Election Commission has a very strategic position for the democratic process in Indonesia. General elections are the largest democratic contestation or people's party to elect various elements of the nation's leaders and people's representatives starting from the regional to the central level. Therefore, in an effort to realize the optimal process and results, the General Election Commission launched a vision: "The realization of the General Election Commission as the organizer of elections that have integrity, professionalism, independence, transparency, and accountability, for the creation of quality Indonesian democracy". This vision is a great vision so that it must be realized by the General Election Commission so that the democratic process in Indonesia can be a role model for other nations in the world. To be able to realize the vision and mission and carry out its duties and obligations, the Provincial Election Commission is required to have quality human resources. Human resources are the main pillars of an organization, so they must have sufficient competence to carry out their duties. Quality human resources will also determine the quality of the holding of general elections so that it further influences the quality of leaders and representatives of the people. This will further affect the nation's development process. This research focuses on taking objects in the General Election Commission of Banten Province. The General Election Commission of Banten Province is a state institution that organizes general elections in Banten Province which was formed in 2003. The problems of human resources as mentioned above also occur in the General Election Commission of Banten Province. So far the quality of the human resources of the General Election Commission in Banten Province still needs to be improved because it is still not optimal. This is reflected in the performance of employees who are generally not 
optimal. Employee performance is an important factor that determines success in the Banten Provincial Election Commission. The important role of performance in influencing the success of the organization in realizing its goals. (Bernadin et al.2009). in Armstrong, "performance as the outcomes of work because they provide the strongest linkage to the strategic goals of the organization, customer satisfaction, and economic contributions." The explanation emphasizes that performance refers to work that has a close relationship with the organization's strategic goals, customer satisfaction, and contribute to the economy. (Watkins and Leigh, 2010), the work is the reason for someone or organization to prioritize activities that can improve performance, such as quality improvement, knowledge management, use of information technology, employee recruitment, training and implementing a balanced scorecard. (Sonnentag and Frese, 2002) explain the following: Organizations need highly performing individuals in order to meet their goals, to deliver the products and services they are specialized in, and finally to achieve competitive disadvantage. Performance is also important for the individual. Accomplishing tasks and performing at a high level can be a source of satisfaction, with feelings of mastery and innovation. Low performance and not achievable goals can be as dissatisfying or even personal failure. The performance of employees who are generally not optimal can be caused by many factors, such as leadership integrity, team cohesiveness, and task commitment. Related to leadership integrity, a leader is a very influential figure in the organization, especially in influencing employee behavior. Thus the leader must have strong integrity to be trusted by his subordinates. In addition to having an impact on performance, the integrity of leaders is also important to increase the commitment of the task and cohesiveness of the team. So far the leadership integrity has not been optimal. Based on the results of preliminary research shows that so far the leadership is considered less transparent in carrying out the promotion process, less assertive in taking action against employees who violate organizational rules or codes of ethics, and lack of objectivity in providing an assessment of employee performance. The team's cohesiveness in the process of completing tasks at the General Election Commission is also very important. That is because, in the process of completing the work, all stages of the election are carried out in a working group that must be completed in a team. While task commitment factors are also important factors to improve performance. Commitment is an energy that will encourage someone to make efforts so that what is the task can be resolved with the best results. People who have a commitment will show a strong sense of responsibility towards their work, so they will work hard for the success of the task. If an employee has a low commitment to carrying out the task, it will show lazy and unmotivated behavior in carrying out his work, so that the impact on the results is also not optimal. The tasks that are the responsibility of employees in the General Election Commission also require a commitment from each employee, so that every employee needs to show a strong commitment to carrying out their duties. In fact, the Banten Provincial Election Commission based on the results of preliminary research shows that employee duty commitments still show less than optimal conditions. This is indicated by the lack of enthusiasm of hard work of employees in carrying out their duties so that they tend to give up easily when finding difficulties and tend to show less of their best work performance. In addition, employees are also less actively involved in activities that are 
useful for improving their work knowledge and skills as well as fast, appropriate and accurate services to stakeholders. If conditions like this continue, it will be detrimental to the organization, which in the end the organization's goals cannot be maximized. In addition to the leadership integrity factor, team cohesiveness and task commitment, there are actually many factors that influence performance. The intended factors such as work environment, organizational culture, compensation, self-efficacy, work attachment, and supervision. These factors contribute to influencing employee work behavior, so that in an effort to strengthen employee performance also needs to get sufficient attention. Referring to problem identification and problem limitation, the research problems can be formulated as follows: (1) Is there a direct influence of leadership integrity on employee performance? (2) Is there a direct effect of team cohesiveness on employee performance? (3) Is there a direct effect of task commitment on employee performance? (4) Is there a direct effect of leadership integrity on employee duty commitments? (5) Is there a direct effect of team cohesiveness on employee task commitment? (6) Is there a direct influence of leadership integrity on the cohesiveness of the team? Based on the description above, the researcher is interested in conducting research with the title: The Influence of Leadership Integrity, Team Cohesiveness and Task Commitment on the Employee Performance of the General Election Commission of Banten Province.

\section{Literature Review}

\subsection{Employees Performance}

(Stephan J. Motowidlo, 2003), "job performance is defined as the total expected value to the organization of the discrete behavioral episodes that an individual carries out over a standard period of time". (Jex and Britt, 2008) "job performance refers to all of the behaviors employees engage in while at work. (Sperry, 2004), "performance refers to an individual's competencies and personal styles as they positively or negatively impact work outcomes". (Landy and Conte, 2013), "job performance is actions or behaviors relevant to the organization's goals; measured in terms of each individual's proficiency. (Aguinis, 2013), Job performance does not include the results of an employee's behaviors but only the behavior themselves. Performance is about behavior or what employee do, not about what employee produce or outcomes of their work. (Brumbach in Armstrong, 2006), Job performance means both behaviors and results. Behaviors emanate from the performer and transform performance from abstraction to action. Not just the instruments for results, behaviors are also outcomes in their own right-the product of mental and physical effort applied to tasks. (Penny and Borman, 2005) Contextual performance differs from task performance in three important ways. First, task behavior varies across jobs, whereas contextual behavior is fairly similar across jobs. For example, carpenters and accountants perform very different tasks, but both may volunteer to work late on projects or offer jobrelated assistance to coworkers in need. Second, task activities are more likely to be formally expected as a job requirement than contextual activities. That is, while an organization may appreciate or benefit from employees who put in extra effort to help others complete their work, those kinds of behaviors are generally considered above and beyond the call of duty. Finally, antecedents of task performance are more likely to involve 
cognitive ability, whereas antecedents of contextual performance are more likely to be dispositional or personality-related. (Byrne, 2015) In-role job performance refers to prescribed behaviors such as completing assigned tasks and attending required when that exists; not all jobs or organizations provide job descriptions. In-role job performance is the work expected of an employee within a given work role. In contrast, extra-role behavior is described as contributing to the effective functioning of the organization and may or not be formally expected of employees or recognized within the reward system. (Shields, 2007), Performance as a system comprising three main elements arranged in a linear sequence (1) 'inputs', including employee knowledge, skills and competencies (i.e. abilities and attitudes), as well as other tangible and intangible 'resources'; (2) human resource activities that transform inputs into outcomes, including, most importantly,work effort and other behaviour; and (3) 'outputs', including outcomes from work behaviour. (Mathis and Jackson, 2011) suggested that in the organization of individual performance employees are the main determinant of organizational success and many factors influence the good or bad of individual performance, namely: 1) the ability of individuals to do work, 2) the level of effort spent, and 3) organizational support. Ability is determined by talent, interest, and personality, while the effort involved includes motivation, work ethics, attendance, work design and which includes support including training, development, equipment and technology, work standards, management, and coworkers. Thus, if the overall factors above are considered by the organization and in optimal conditions, then individual performance can be optimized. (Lepak et al., 2006), The direct determinants of job performance are declarative knowledge, procedural knowledge and skill, and motivation. Declarative knowledge refers to knowledge or facts, principles, and procedures needed to carry out work tasks. Procedural knowledge and skill refer to skills in actually doing what should be done, therefore is a combination of knowing what to do and how to do it. Motivation consists of an individual's direction, intensity, and duration of the effort. Motivation manifests in the individual's choices to exert effort, choices of how much effort to exert, and choices of how long to exert the effort. Individuals' knowledge, skill, and motivation combine and interact with each other to determine job performance. Other individual differences factors such as cognitive ability, experiences and personality, and contextual factors such as task characteristics and training are said to indirectly influence job performance via their impact on the individuals' knowledge, skills, and motivation. (Dessler, 2013), "performance appraisal means evaluating an employee's current and/or past performance relative to his standard. (Gómez-Mejía, Balkin, and Cardy, 2012): "performance appraisal refers to the identification, measurement, and management of human performance in organizations." (Mathis and Jackson, 2011, First, trait-based information identifies a character trait of the employee - such as attitude, initiative, or creativity-and may or may not be job-related. Second, behavior-based information focuses on specific behaviors that lead to job success. Third, results-based information considers employee accomplishment. For jobs in which measurement is easy and obvious, a resultsbased approach works well. (Borman, 2005) for Viswesvaran dan Ones: Personal Support. Helping others for teaching them useful knowledge or skills, directly performing some of their tasks, and providing emotional support for their personal problems. Cooperating with others by accepting suggestions, informing them of events they should know about, and 
putting team objectives ahead of personal interests. Showing consideration courtesy, and tact in relations with others as well as motivating and showing confidence in them. Organizational Support. Representing the organization favorably by defending and promoting it, as well as expressing satisfaction and showing loyalty by staying with the organization despite temporary hardships. Supporting the organization's mission and objectives, complying with organizational rules and procedures, and suggesting improvements. Taking the initiative to do all that is necessary to accomplish objectives even if not normally a part of own duties, and finding additional productive work to perform when own duties are completed. Developing own knowledge and skills by taking advantage of opportunities within the organization and outside the organization using own time and resources. (Viswesvaran and Ones, 2005) identified seven dimensions of performance as follows: (1) Productivity or task performance. (2) Interpersonal competencies. (3) Leadership. (4) Business. (5) Work knowledge. (6) Counterproductive behavior. (7) Good organizational citizen behavior. Also referred to as contextual performance, prosocial behavior, and altruism. (Pulakos, Dorsey, and Borman, 2003) specifically related to the knowledge dimension explain some indicators that can be a measure of performance. First, building and applying knowledge. This is done by gathering information and filtering to identify key issues and gain an understanding of the situation, analyze data, integrate data, and think outside the box to create new knowledge, increase the knowledge base, or develop solutions, develop new strategies and innovations, utilizing technology to improve productivity and performance. Second, knowledge sharing.

\subsection{Leadership Integrity}

(Resick et al. 2009), Integrity is a fundamental component of character and entails the ability to both determine, as well as engage in morally correct behavior regardless of the external pressures that may be present. Moreover, leader integrity is a critical factor for ensuring the effective management of ethical dilemmas across cultures. Leader character and integrity are important components of ethical leadership because they are personal characteristics that influence the choices and actions that leaders make and ways that leaders use their social power. (Kibok, 2003), Integrity is defined as the audience's perception that the leader adheres to a set of principles that the audience finds acceptable. In order for a leader to be perceived as a person of integrity, he/she needs to show equality between words and behavior, consistency with his/her past actions, credible communications with the audience, and a strong sense of justice. Hence the leader who is perceived to be trustworthy with regard to his/her ability, benevolence and integrity will be more likely to succeed in attempts to involve the audience in the focal issue. (Parry and Proctor-Thompson, 2008), for Atwater \& Waldman, "leader integrity in term of commitment in action to a morally justifiable set of principles an values." (Simons et al., 2009) for Moorman dan Grover, "behavioral integrity refers to both a pattern of consistency between leaders' espoused values and their actions and also the extent to which promises are kept." (Terry, 2015), "the word integrity refers to the completeness, wholeness, and intact quality of an entity." (Barbara Killinger, 2010) "integrity is a personal choice, an uncompromising and predictably consistent commitment to honor moral, ethical, spiritual, and artistic values and principles." (Brown, 2005), explains that 
integrity contains at least four meanings. First, integrity is consistency (integrity as consistency). Second, integrity is a relational awareness (integrity as relational awareness). Third, integrity as inclusion (integrity as inclusion). Fourth, integrity as pursuing beneficial goals. (Blankson, 2005), "integrity is the steadfast adherence to a strict moral or ethical code, the state being of being unimpaired and undivided in its continuous application, whilst constantly improving on this state." Catlett dan Firestone (2009-286) Leaders who have integrity are those whose actions correspond to their words and are thereby able to inspire trust in others. Integrity is perhaps the most important characteristics that an effective leader needs to possess or develop. (Blankson, 2005) integrity contains three main aspects, first, firm obedience, second, being unimpaired and undivided, third, make continuous improvements. (Beebe, 2005), Integrity is: (1) an inner psychological harmony, or wholeness; (2) a conformity of a personal expression with psychological reality - of act with desire, of word with thought, of face with mind, of the outer with the inner self, and (3) an extension of wholeness and conformity with time, through thick and thin. Though integrity can be and must be, expressed in individual actions, it is not fully realized except in terms of continuity. (Petrick and Quinn, 2001) "the quality of moral self- governance at the individual and collective levels." (Hooijberg, Lane and Diverse, 2010), the correspondence between one's words and actions, how well people match their espoused values to their actual values. (Steve WJ Kozlowski at.al, 2003) In an effort to instill integrity, organizations can develop a vision that emphasizes aspects or principles of doing what is right, respecting others, and doing work with results. best (performing with excellence). (Aubuchon, 2003), Integrity, among others, is characterized by three things. First, honesty, second, truthfulness, third, character. (Blankson, 2004) to build integrity, it is necessary to have key principles that a person needs to have. The eight principles needed to build integrity, namely: love (honesty), honesty (honesty), faith and hope (faith and hope), prudence (prudence), justice (justice), fortitude (fortitude), piety (charity), and self-control (temperance). Based on the description above, it can be synthesized that leadership integrity is a match between the words and actions shown by the leader in carrying out their daily tasks with indicators: honesty, reliable, trustworthy, keeping promises, fighting for the truth, acting cautiously, having character, acting fairly, having fortitude, and being able to control himself.

\subsection{Team Cohesiveness}

(Wood et.al., 2013) "teams are small groups of people with complementary skills, who work together as a unit to achieve a common purpose for which they hold themselves collectively accountable". (Lussier and Achua, 2007): A team is a unit of two or more people with complementary skills who are committed to a committed to the purpose and set of performance goals and to common expectations, for which they hold themselves accountable. (Kinicki and Kreitner, 2008), a group is said to be a team if it meets four criteria, namely: (1) leadership becomes a joint activity, (2) responsibility increases from high individual to individual and group, (3) groups develop their own goals or mission of the organization, (4) problem solving becomes a way of life, not part of activity, and (5) effectiveness is measured by products and collective results. (Daft and Marcic, 2009), "team cohesiveness is defined as the extent to which members are attracted to the team 
and motivated to remain in it." (Palmer, 2011), "team cohesiveness refers to the ability of team members to stick together and the ability of the team to attract new members." (McShane, Olekalns and Travaglione, 2013), "team cohesion refers to the degree of attraction that people feel towards the team and their motivation to remain members". (Hitt, Miller and Colella, 2011) "team cohesion refers to members' attraction to the team". (Aamodt, 2013) "group cohesiveness refers to the extent to which members of a group like and trust one another". (Wood, et al., 2013) "team cohesiveness the degree to which members are attracted to, and motivated to remain part of a team". (Spoor \& Kelly for Slocum and Hellriegel, 2007) "cohesiveness is the strength of members' desire to remain in a team and their commitment to it". (Katzenbach \& Smith quoted by Wood et al., 2013) show several ways: (1) communicating clear high performance standards, (2) establishing patterns in the team's first meeting, (3) creating a sense of urgency; establish contexts that force action, (4) ensure team members have the right skills, (5) establish clear rules for team behavior, (6) team leaders become behavioral role models, (7) identify specific targets that can be achieved to create initial success, (8) continuously introducing new facts and information to the team, (9) ensuring team members spend time together, and (10) giving positive feedback; rewards and recognition for high performance. (Andrew, Szilagyi, Jr., and Wallace, Jr. adapted by Luthans, 2011), also developed a model that explained the factors that led to a decrease and increase in cohesiveness. Group cohesiveness will increase if there is agreement on group goals, frequency of interactions, personal interest, competition in the group and satisfactory evaluation. Factors that can reduce cohesiveness include goal disagreement, large group size, unpleasant experiences, inter-group competition, and dominance by one or several group members. (Greenberg, 2010) mentions four factors that influence team cohesiveness. First severity of initiation. Second external threat. Third group size. Fourth history of success. There is often an expression that everyone loves victory, and success for groups tends to help unite its members. (Dessler and Phillips, 2008) show how to create effective teams, namely: creating synergy, developing cohesiveness, creating trust, preventing social laziness, establishing clear roles, preventing decision making that does not consider all alternatives, establishing positive norms, creating shared team goals, provide appropriate rewards, use appropriate team sizes, integrate new members, and gain emotional intelligence. (Yukelson et al., Cited Marcos et al. 2010). formulating 4 aspects of cohesiveness, namely: (1) Teamwork. (2) Value roles. (3) Unity of purpose. (4) attraction to the group. Chen (201383), four factors for measuring cohesiveness, namely teamwork, interpersonal affinity, team adaptation, and interpersonal attraction. (Carron et al., for Huang, 2009), four cohesivity: Group cohesiveness has also been conceptualized under four dimensions: (a) Individual attractions to the group-task: The individual member's perceptions of his or her personal involvement with the group task; (b) Group integration-task: The individual member's perceptions of the similarity, closeness, and bonding existing within the group in the context of its collective task; (c) Individual attractions to the group-social: The individual member's perceptions of his or her personal acceptance and social interaction with the group, and (d) Group integration-social: The individual group member's perceptions of the similarity, closeness, and bonding within the group in the context of social concerns. Thus, group cohesiveness should be focused on either the social or the 
task-related aspect of the group. (Salas et al., 2015): (1) Task. An attraction or bonding between group members that is based on a shared commitment to achieving the group's goals and objectives, (2) Social. A closeness and attraction within the group that is based on social relationships within the group, (3) Belongingness. The degree to which members of a group are attracted to each other, (4) Group pride. The extent to which group members exhibit liking for the status or the ideologies that the group supports or represents, or the shared importance of being a member of the group, (5) Morale. Individuals' high degree of loyalty to fellow group members and their willingness to endure frustration for the group. (Widmeyer et al., for Carless and Caroline De Paola, 2000): (a) Group Integration-Task, which is an individual team member's perceptions about the similarity and closeness within the team about accomplishing the task; (b) Group Integration-Social, which reflects individual team member's perceptions about closeness and bonding regarding the team's social activities; (c) Individual Attraction to Group-Task, which describes individual team members' feelings about personal involvement in the group task; and (d) Individual Attraction to Group-Social, which reflects individual team members' feelings about personal involvement in the social interaction of the group. Based on the description of the concept above, it can be synthesized that team cohesiveness is the bond felt by team members that encourage maintaining membership in the team and creates mutual trust between team members as measured by indicators: mutual trust, cooperation, respecting team values, unity of purpose, interest in the team, adaptation in the team, and involvement in the team.

\subsection{Task Commitment}

(Purohit \& Nayak, 2003), "commitment refers to the motivation and the willingness of the individual members to set and accept challenging goals, to take responsibility, their involvement in work, and their job satisfaction." (Cole and Bedeian, 2007), "commitment within a workplace setting encompasses an individual's emotional attachment to a particular organization. It is characterized by a tendency to internalize work-related problems and a willingness to go the extra distance". (Peng et al., 2009) "commitment is a key concept in organizational psychology. It refers to the number of resources and effort that an individual is willing to invest in his or her work role". (Ugboro, 2006), there are four basic understandings of commitment: (1) the strong willingness of a person to identify with and a desire not to leave the organization for its own sake or for a certain advantage; (2) a strong willingness to work alone and contribute to the effectiveness of the organization (3) a strong desire to sacrifice alone, work beyond time limits and normal expectations within the organization; and (4) acceptance of organizational values and goals as an internalization factor. Specifically related to task commitment. (Nakatsu \& Grossman, 2013) "task commitment refers to the amount of effort and resources that are required to perform a task or solve a problem". (MacCoun et.al.for Salas, Estrada \& Vessey, 2015), "task commitment refers to the group's shared commitment to the group task and their motivation to complete the task." (Dent \& Craig, 2001). Task commitment is the energy or motivation that is directed toward a project or goal. This personal characteristic is demonstrated by a focused manner of accomplishing tasks. People who are task-committed have the ability to chart a course of action and to follow it to goal 
completion. (Renzulli, 2003), "task commitment are perseverance, endurance, hard work, dedicated practice, self-confidence, and belief in one's ability to carry out important work." (Silverthorne, 2005) explained that the elements of mutual obligations and satisfaction included the dimensions of commitment in the organizational context. Mutual obligations are meaningful, the assignment provides positive certainty towards the attainment of the tasks. Macey and Schneider, 2008) associate bonds with work motivation. In addition, the connotation of the meaning of the bond exists in the context of organizational goals, and parallel with the meaning of total involvement (involvement), commitment, enthusiasm, passion in work (passion), focused effort, and energy. (Armstrong, 2006) states that there are three factors forming commitment in carrying out tasks: First, a strong desire to remain a member of the organization. Second, the existence of the trust and strong acceptance of the values of funds of organizational goals; and thirdly, there is a readiness to issue the strongest abilities with efforts that can be considered from the half of the target achievement of the organization. (Gostick and Elton, 2004) formulated a definition of commitment in the organization as a psychological construct which is a characteristic of the relationship between members of the organization and its organization and has implications for individual decisions to continue their membership in the organization. Based on these definitions, members who are committed to their organization will be more able to survive as part of the organization members who have no commitment to the organization. (Porter et al. for Armstrong, 2006) Organizational commitment refers to attachment and loyalty. It is the relative strength of the individual's identification with, and involvement in, a particular organization. It consists of three factors: (1) A strong desire to remain a member of the organization, (2) A strong belief in, and acceptance of, the values and goals of the organization, and (3) A readiness to exert considerable effort on behalf of the organization. (Weick and Quinn, 1999) understand sustainable change as a change in the body of an organization that tends to be a continuous change, evolve, and reach a cumulative point. (Armstrong, 2006), there are several strategies for developing task commitment members: a) Communicate the values and objectives of the management and efforts to achieve the organization, so that employees become more interested in identifying values and goals as a form of pride of occupation; b) Demonstrate to employees that management is committed to them by acknowledging their contribution as "stakeholders" and striving to maximize the security of employment; c) develop a climate of trust (assurance of climate) with the assurance that the management is honest with people, be fair, maintain words and willingness to listen to comments and suggestions made by workers during the consultation and participation process takes place; d) Creating positive psychological contracts with attitudes to employees as "shareholders", which runs in accordance with consensus and cooperation rather than acting with a system of supervision and emphasis, and focusing on providing opportunities for workers to learning, for career advancement and development; e) Develop performance management processes to synergize between personal goals and organization; f) Helping employees to add recognition to the organization by giving rewards that are associated with organizational performance (profit sharing) or through ownership schemes distributed to employees (employee share ownership schemes); and g) develop and maintain a work environment that makes the organization an "employer of choice" because the place where they work is 
an extraordinary place (a great place to work). Based on the description of the concept above, it can be synthesized that task commitment is the level of motivation and willingness of individuals to carry out efforts directed at completing their tasks with indicators: perseverance, responsibility, accepting work challenges, work involvement, hard work, and self-confidence.

\subsection{Relevant Research Results}

(Ismail, Khurram, and Jafri, 2011) in their research entitled, "Role of Leaders' Behavioral Integrity In Determining Successful TQM Implementation and Organizational Performance: A Study on Public Hospitals of Pakistan". His research was conducted on employees in a number of hospitals in Lahore City, Pakistan with a sample of 100 employees. His research uses a quantitative approach with data collection using a 1-5 Likert scale questionnaire and the data analysis technique with regression. The results of his research, among others, showed that leadership integrity had a significant effect on performance. (Pillai and Williams, 2004), with his research entitled: "Transformational leadership, self-efficacy, group cohesiveness, commitment, and performance". His research was conducted on employees of the Fire Department in the United States with a sample of 271 people. His research uses a quantitative approach with data collection using questionnaires and data analysis techniques with SEM. The results of his research include concluding that team cohesiveness affects employee performance. (Fu and Deshpande, 2014), in his research entitled: "The Impact of Caring Climate, Job Satisfaction, and Organizational Commitment on Job Performance of Employees in a China 's Insurance Company". His research was conducted on employees of insurance companies in China with a total sample of 476 . His research used a quantitative approach with data collection using 1-5 scale questionnaires and data analysis techniques with SEM. The results of his research include concluding that commitment affects performance. (Davis and Rothstein, 2006), as seen in his research entitled: "The Effects of the Perceived Behavioral Integrity of Managers on Employee Attitudes: A Meta-Analysis". His research is a meta-analysis study involving a study of 21 research results. The results of his research include showing that the manager's integrity behavior influences commitment. (Al-Rawi, 2008), as seen in his research entitled "Cohesiveness within Teamwork: the Relationship to Performance Effectiveness: Case Study". His research was conducted on government employees in Abu Dhabi with a sample of 294 people. His research uses a quantitative approach with data collection using 1-7 scale questionnaires and data analysis techniques with SEM. The results of his research include concluding that team cohesiveness has an effect on commitment. (Jenster, 2009) as seen in his research entitled: "Leadership Impact on Motivation, Cohesiveness Effectiveness in Virtual Teams: A Perspective FIRO". His research uses a quantitative approach with a sample of 221. Data collection uses a 1-7 scale questionnaire and correlational data analysis techniques. The results of his research include concluding that leader behavior, among others, indicated by integrity influences the cohesiveness of the team.

\subsection{Hypothesis}

Based on the literature review and the results of previous research and theoretical 
frameworks, the research hypothesis can be formulated as follows: (1) There is a positive direct effect of leadership integrity on employee performance. (2) There is a positive direct influence of team cohesiveness on employee performance, (3) There is a positive direct effect of task commitment on employee performance, (4) There is a positive direct effect of leadership integrity on employee duty commitments, (5) There is a positive direct influence on team cohesiveness. employee duty commitment, (6) There is a positive direct effect of leadership integrity on team cohesiveness.

\section{Methods}

\subsection{Research Design}

This study uses a quantitative approach, and the research method used is a survey method with causal techniques. (Nandagopal, Rajan, and Vivek, 2008), causal research refers to the existence of a cause and effect relationship. This research provides evidence that suggests whether a cause and effect relationship exists or does not exist. It describes whether an independent variable directly influences the behavior of a dependent variable. (Kadir, 2010) for analyzing the presence or absence of influence between one variable and another variable is done using path analysis.

\subsection{Population}

(Husen Umar, 2003) The population is employees of the General Election Commission of Banten Province. As an affordable population or target population for the sample frame is an executive-level employee with S1 and S2 education at the General Election Commission in Banten Province, amounting to 153 people. To determine how many samples were taken, the Slovin formula was used with an error rate of $5 \%$. Based on the results of the above calculations, it is determined that the number of research samples is 111 employees of the General Election Commission of Banten Province. Sampling is done by simple random sampling through lottery techniques. Given that the study population is spread in several places, then to determine the number of samples in each place carried out proportionally.

Table 1. Details of Number of Populations and Research Samples

\begin{tabular}{|c|l|c|c|}
\hline No & Description & $\begin{array}{c}\text { Total of } \\
\text { Employee }\end{array}$ & Sample \\
\hline 1 & Election Commission-Banten Province & 25 & $\frac{25}{153} x 111=18$ \\
\hline 2 & Election Commission-Serang Regency & 16 & $\frac{16}{153} \times 111=12$ \\
\hline 3 & Election Commission-Serang City & 14 & $\frac{14}{153} x 111=10$ \\
\hline 4 & Election Commission-Cilegon City & 19 & $\frac{19}{153} \times 111=14$ \\
\hline 5 & Election Commission-Pandeglang Regency & 20 & $\frac{20}{153} x 111=15$ \\
\hline
\end{tabular}




\begin{tabular}{|c|l|c|c|}
\hline 6 & Election Commission-Lebak Regency & 14 & $\frac{14}{153} \times 111=10$ \\
\hline 7 & Election Commission-Tangerang Regency & 13 & $\frac{13}{153} x 111=9$ \\
\hline 8 & Election Commission-Tangerang City & 19 & $\frac{19}{153} x 111=14$ \\
\hline 9 & Election Commission-South Tangerang City & 13 & $\frac{13}{153} x 111=9$ \\
\hline \multicolumn{2}{|l|}{ Total } & $\mathbf{1 5 3}$ & $\mathbf{1 1 1}$ \\
\hline
\end{tabular}

\subsection{Research Instrument}

The technique of collecting data in field research using an instrument in the form of a questionnaire. (Creswell, 2012), a questionnaire used in a survey design that participants complete and return to the researcher. The participant chooses answers to questions and basic personal or demographic information ".

\section{Results}

From the calculation of path analysis in each structural equation can be made in the path diagram as follows:

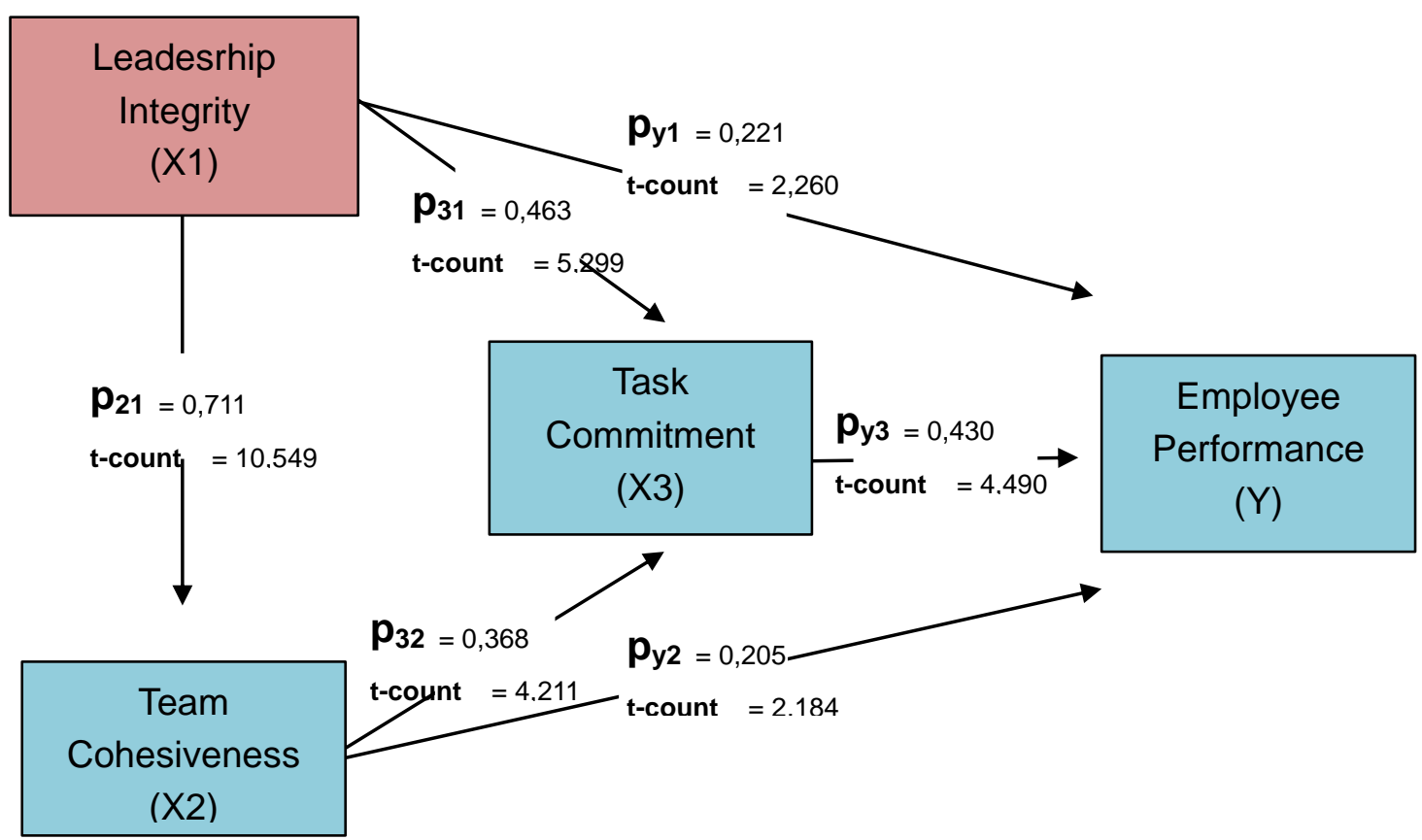

$$
\text { p-value }=1,000, \text { RMSEA }=0,000
$$

Picture 1. Results of Analysis of the Effect of Leadership Integrity, Team Cohesiveness and Task Commitment to Employee Performance

The results of hypothesis testing indicate that the six hypotheses tested in this study were accepted. This shows that leadership integrity, team cohesiveness, and task commitment have a positive direct effect on performance; leadership integrity and team cohesiveness 
have a positive direct effect on task commitment and leadership integrity has a positive direct effect on team cohesiveness.

\section{Discussion}

The discussion is carried out by linking findings and theories and the results of previous research and supporting facts. The first finding of this study is that leadership integrity has a positive direct influence on the performance of employees in the General Election Commission of Banten Province. This means that leaders who have high integrity will have an impact on increasing employee performance. (Resick et al., 2009), integrity is a fundamental component of character and entails the ability to both determine, as well as engage in morally correct behavior regardless of the external pressures that may be present. Moreover, leader integrity is a critical factor for ensuring the effective management of ethical dilemmas across cultures. Leader character and integrity are important components of ethical leadership because they are personal characteristics that influence the choices and actions that leaders make and ways that leaders use their social power. (Catlett and Firestone, 2009), Leaders who have integrity are those whose actions correspond to their words and are thereby able to inspire trust in others. Integrity is perhaps the most important characteristics that an effective leader needs to possess or develop. (Becker for Storr, 2004), "the value of integrity in the workplace: (1) a predictor of job performance; (2) a determinant of behaviors; (3) a central determinant of trust; and (4) a central trait of effective leaders and organizational success". (Rumsey, 2013), "integrity is important in leaders because it engenders trust. Being able to trust one's manager is associated with a range of positive leadership outcomes, including enhancing job performance, job satisfaction, and organizational commitment." (Gully, 2014), "integrity tests do not tend to result in adverse impact and appear to be unrelated to cognitive ability, they can add value in predicting job performance and reduce the adverse impact of cognitive ability test." (Ismail, Khurram, and Jafri, 2011), the results of his research show that leadership integrity has a significant effect on performance. From theoretical studies and previous research, the position of this research is to strengthen the theory and previous research related to the influence of leadership integrity on performance. (Aamodt, 2010), "group cohesiveness refers to the extent to which members of a group like and trust one another". (Cohen et al. for White \& Lean, 2008), "teamwork design offers numerous benefits, such as the improvement of performance, productivity, cost reduction, and employee satisfaction." (Wood et al, 2010). "effective teams tend to have higher morale, higher productivity, greater pride in the job, and greater pride in the company". (Robbins and Coulter, 2012), Cohesiveness is important because it has been found to be related to a group's productivity. Groups in which there's a lot of internal disagreement and lack of cooperation are less effective in completing their tasks than groups in which members generally agree, cooperate, and like each other. (Pillai and Williams, 2004), the results of his study concluded that team cohesiveness had an effect on employee performance. (Wechet at. al. 1998) which also shows the results that individuals in cohesive groups show higher performance. (Purohit and Nayak, 2003), "commitment refers to the motivation and the willingness of the individual members to set and accept challenging goals, to take responsibility, their involvement in work, and their job satisfaction." (Peng 
et al., 2009), "commitment is a key concept in organizational psychology. It refers to the number of resources and effort that an individual is willing to invest in his or her work role". (Nakatsu and Grossman, 2013), "task commitment refers to the amount of effort and resources that are required to perform a task or solve a problem". (Dent and Craig, 2001): Task commitment is the energy or motivation that is directed toward a project or goal. This personal characteristic is demonstrated by a focused manner of accomplishing tasks. People who are task-committed have the ability to chart a course of action and to follow it to goal completion. (McCloy and Wise, 2002) that commitment is very likely related to motivation to improve performance because when individuals commit to their work, they will have the desire to improve it. Cooper (2004-31) that commitment is an important factor related to performance. Strong commitment will lead to improved performance. Thus, the position of this research is to support and strengthen the theory and previous research on the effect of task commitment on performance. The results of statistical tests show that leadership integrity has a positive direct influence on employee task commitment in the Banten Provincial Election Commission. (Simons, 1999), which proves that the integrity of a leader is important to improve employee task commitment because integrity is the main capital for a leader to gain trust from subordinates so that it will be easier to influence subordinates. Integrity deals with the harmony between words and actions. (Heineman, 2008) as manifested in the form of firm adherence to regulations, voluntarily adopting global ethical standards and commitment to values. (Salari and Torre, 2013), that leadership integrity will affect the commitment of subordinates. (Leroy, Polanski, and Simons, 2012), whose results also show that leadership integrity behavior influences subordinate commitment. Thus, the position of this research is to support and strengthen the theory and previous research on the influence of leadership integrity on task commitment. The results of statistical tests show that team cohesiveness has a positive direct influence on employee task commitment in the Banten Provincial Election Commission. (Spoor and Kelly in Slocum and Hellriegel, 2007), cohesiveness is the strength of the members' will to survive in a team and its commitment to the team. (Colquitt, LePine, and Wesson, 2015), teamwork processes have a strong positive effect on Team Commitment. That aspect of the process has a stronger effect on commitment for teams involved in more complex knowledge work rather than less complex work. (AlRawi, 2008) also concluded that team cohesiveness had an effect on commitment. (Weick et al., 1999) found cohesiveness had an impact on commitment. Thus, the position of the research results supports the theory and previous studies related to the influence of team cohesiveness on task commitment. The results of statistical testing with path analysis show the results that leadership integrity has a positive direct influence on the cohesiveness of the team within the General Election Commission of Banten Province. (Catlett and Firestone, 2009), leaders who have integrity are those whose actions correspond to their words and are thereby able to inspire trust in others. Integrity is perhaps the most important characteristics that an effective leader needs to possess or develop. (Gibson et al., 2012): The leadership role in groups is a crucial group characteristic because the leader plays an important role in determining group success. The leader of a group exerts some influence over group members. In the formal group, the leader can exercise legitimately sanctioned power. That is, the leader can reward or punish members who don't comply 
with directives, orders, or rules. (White and Lean, 2008), the integrity of leaders may be the primary driving influence on subordinates' behaviors with regard to ethical issues involving other individuals. (Jenster, 2009) also concluded that leader behavior, which among others was demonstrated by integrity, had an effect on team cohesiveness. Thus, the position of this research is to support and strengthen the theory and previous research on the influence of leadership integrity on team cohesiveness.

\subsection{Conclusion}

There is a positive direct effect of leadership integrity on the performance of employees in the General Election Commission of Banten Province. This means that high leader integrity is demonstrated by honesty, is reliable, trustworthy, keeps promises, fights for truth, acts cautiously, has character, acts fairly, has fortitude and is able to control oneself will have an impact on increasing employee performance. There is a positive direct effect of team cohesiveness on the performance of employees in the General Election Commission of Banten Province. This means that the team that has high cohesiveness is shown by mutual trust, cooperation, respect for team values, unity in objectives, team attraction, adaptation in teams, and involvement in teams will have an impact on increasing employee performance. There is a positive direct effect on task commitment to the performance of employees in the General Election Commission of Banten Province. This means that employees who have high duty commitments are shown by perseverance, responsibility, accepting work challenges, work involvement, working hard, and selfconfidence will have an impact on increasing employee performance. There is a positive direct effect of leadership integrity on employee duty commitments within the Banten Provincial Election Commission. It means that high leader integrity by being shown honesty, being reliable, trustworthy, keeping promises, fighting for truth, acting cautiously, having character, acting fairly, having fortitude and being able to control themselves will have an impact on increasing employee duty commitment. There is a positive direct effect of the team's cohesiveness on the employee's commitment to the Banten Provincial Election Commission. This means that the team that has high cohesiveness is shown by mutual trust, cooperation, respect for team values, unity of goals, interest in the team, adaptation in the team, and involvement in the team will have an impact on increasing employee task commitment. There is a positive direct effect of leadership integrity having a positive direct influence on the cohesiveness of the team in the Banten Provincial Election Commission. This means that high leader integrity by being shown honesty, being reliable, trustworthy, keeping promises, fighting for truth, acting cautiously, having character, acting fairly, having fortitude and being able to control oneself will have an impact on the cohesiveness of the employee team.

\section{Acknowledgments}

We would like to say thank especially to Hamidah, Agung Darmawan,.Elkana, Setia Budi and Usep Suhud, for their contribution to the research.

\section{References}

Aamodt, M. G. (2013). Applying Psychology to Work. Canada: Wadsworth, Cengage 
Learning.

Aguinis (2013). Herman. Performance Management. New Jersey: Pearson Education, Inc.

Al-Rawi, K. (2008). Cohesiveness within teamwork: the relationship to performance effectiveness - case study. Education, Business and Society: Contemporary Middle Eastern Issues, 1(2). https://doi.org/10.1108/17537980810890284

Armstrong, M. (2006). A Handbook of Human Resource Management Practice. London: Kogan Page.

Atwater, L. E., \& David, A. (2008). Waldman. Leadership, Feedback and the Open Communication Gap. New York: Francis \& Taylor Group.

Aubuchon, D. (2003). Integrity: Do You Have It? Lincoln: Universum Inc.

Baik, K. (2003). Issue Leadership Theory and Its Implications In Global Settings, eds. William H. Mobley dan Peter D. Dorfman. Oxford: Elsevier.

Beebe, J. (2005). Integrity in Depth. New York: Library of Congress Cataloging-inPublication Data.

Blankson, S. (2005). Developing Personal Integrity. Raleigh: Lulu Press Incorporated.

Brown, M. (2005). Corporate Integrity: Rethinking Organizational Ethics and Leadership. Cambridge: Cambridge University Press. https://doi.org/10.1017/CBO9780511753718

Byrne, Z. S. (2015). Understanding Employee Engagement: Theory, Research, and Practice. New York: Routledge. https://doi.org/10.4324/9780203385944

Carless, S. A., \& Caroline, D. P. (2000). "The Measurement Of Cohesion In Work Teams". Small-Group Research Journal, 31(1). https://doi.org/10.1177/104649640003100104

Catlett, J. dan R. W. F. (2009). The Ethics of Interpersonal Relationships. London: Karnac Books, Ltd.

Chen, C.-C. (2013). "How Does Paternalistic Style Leadership Relate to Team Cohesiveness in Soccer Coaching?". Social Behavior and Personality, 41(1). https://doi.org/10.2224/sbp.2013.41.1.83

Cole, M. S., \& Arthur, G. B. (2007). "Leadership Consensus as A Cross-Level Contextual Moderator of The Emotional Exhaustion-Work Commitment Relationship". The Leadership Quarterly, 18. https://doi.org/10.1016/j.leaqua.2007.07.002

Colquitt, J. A., Jeffery, A., \& Lepine, dan M. J. W. (2015). Organizational Behavior: Improving Performance and Commitment in the Workplace. New York: McGraw-Hill Companies, Inc.

Cooper, D. J. (2004). Improving People Performance in Construction. Aldershot: Gower Publishing Limited.

Creswell, J. W. (2012). Educational Research: Planning, Conducting and Evaluating 
Quantitative and Qualitative Research. Boston, MA: Pearson Education, Inc.

Daft, R. L., \& Dorothy, M. (2009). Understanding Management. Mason: Thomson Higher Education.

Davis, A. L., \& Hannah, R. R. (2006). "The Effects of the Perceived Behavioral Integrity of Managers on Employee Attitudes: A Meta-Analysis". Journal of Business Ethics, 67. https://doi.org/10.1007/s10551-006-9034-4

Dent, K., \& Susan, C. (2001). Take Five. San Luis Obispo: Dandy Lion Publications.

Dessler, G. (2011). Human Resources Management. Essex: Pearson Education Limited.

Dessler, G., \& dan, J. P. (2008). Managing Now. Boston: Houghton Mifflin Company.

Fu, W., \& dan, S. P. D. (2014). "The Impact of Caring Climate, Job Satisfaction, and Organizational Commitment on Job Performance of Employees in a China's Insurance Company". Journal of Business Ethics, 24(2).

Gibson, J. L., John M. I., James, H. D., \& Robert, K. (2012). Organizations: Behavior, Structure, Processes. New York: McGraw-Hill Companies, Inc.

Gómez-Mejía, L. R., \& David, B. B. Managing Human Resources. New Jersey: Pearson Education, Inc.

Gostick, A., \& Chester, E. (2004). Managing with Charrot: Metode Penghargaan untuk Menarik dan Mempertahankan Pekerja Terbaik Anda. terjemahan oleh Brati Ambarini. Jakarta: Bhuana Ilmu Populer.

Greenberg, J. (2010). Managing Behaviour in Organizations. New Jersey: Pearson Education Inc.

Hair, J. F., Jr, William, C. B., Barry, J. B., \& Rolph, E. A. (2010). Multivariate Data Analysis: A Global Perspective. New Jersey: Pearson Education, Inc.

Heineman, B. W. (2008). High Performance with High Integrity. Harvard: Harvard University Press.

Hitt, M. A. C., Chet, M., \& Adrienne, C. (2011). Organizational Behavior. New Jersey: John Wiley \& Sons, Inc.

Hooijberg, R., Nancy, L., \& Albert, D. (2010). "Leader Effectiveness and Integrity: Wishful Thinking?," International Journal of Organizational Analysis, 18(1).

Huang, C.-C. (2009). "Knowledge Sharing and Group Cohesiveness on Performance: An Empirical Study of Technology R\&D Teams in Taiwan”. Technovation, 29.

Ismail, K., Wafa, K., \& dan, S. K. A. J. (2011). "Role of Leaders' Behavioral Integrity In Determining Successful TQM Implementation and Organizational Performance: A Study on Public Hospitals of Pakistan”. International Journal of Humanities and Social Science, $1(10)$. 
Jenster, N. P. (2009). "Leadership Impact on Motivation, Cohesiveness, and Effectiveness in Virtual Teams: A FIRO Perspective”. Dissertation. Yongpu: Tongji University.

Jex, S. M., \& Thomas, W. B. (2008). Psychology: A Scientist-Practitioner Approach. New Jersey: John Wiley \& Sons, Inc.

Kadir, S. (2010). Research for Social Science. Jakarta: Rosemata Sampurna.

Killinger, B. (2010). .Integrity: Doing the Right Thing for the Right Reason. Canada: McGill-Queen's University Press.

Kinicki, A., \& Robert, K. (2008). Organizational Behavior: Key Concepts, Skills \& Best Practice. New York: McGraw-Hill.

Kozlowski, S. W. J., \& Bradford, S. B. (2003). Work Groups and Teams in Organizations, eds. Walter C. Borman, Daniel R. Ilgen and Richard J. Klimoski. New Jersey: John Wiley \& Sons, Inc.

Landy, F. J., \& dan J. M. C. (2013). Work in The 21 $1^{\text {st }}$ Century: An Introduction to Industrial and Organizational Psychology. Mason: John Wiley \& Sons, Inc.

Lepak, D. P., Hui Liao, Yunhyung Chung, \& dan E. E. H. (2006). A Conceptual Review of Human Resource Management Systems In Strategic Human Resource Management Research. Oxford: Elsevier Ltd.

Lussier, R. N., \& dan, C. F. A. (2007). Effective Leadership. Canada: Thomson SouthWestern.

Luthans, F. (2011). Organizational Behavior: An Evidence-Based Approach. New York: McGraw-Hill/Irwin.

Macey, W. H., \& Benjamin, S. (2008). "The Meaning of Employee Engagement". Industrial and Organizational Psychology, 1.

Marcos, F. M. L., Pedro, A. S. M., David, S. O., \& Tomás, G. C. (2010), ’Interactive Effects of Team Cohesion on Perceived Efficacy in Semi-Professional Sport". Journal of Sports Science and Medicine, 9.

Mathis, R. L. \& John, H. J. (2011). Human Resource Management. Mason, OH: SouthWestern Cengage Learning.

McCloy, R. A., \& Lauress, L. W. (2002). "Invited Reaction: The Effects of Personality, Affectivity, and Work Commitment on Motivation to Improve Work Through Learning". Human Resource Development Quarterly, 13(4).

McShane, S. Mara, O., \& Tony, T. (2013). Organizational Behaviour: Emerging Knowledge, Global Insights. Sydney: McGraw-Hill Australia Pty Limited.

Moorman, R. H., \& Steven, G. (2009). "Why Does Leader Integrity Matter to Followers? An Uncertainty Management-Based Explanation”. International Journal of Leadership Studies, 5(2). 
Motowidlo, S. J., Job Performance, eds. Walter, C. B., Daniel, R. I., \& Richard, J. K. (2003). New Jersey: John Wiley \& Sons, Inc.

Nakatsu, R., \& Elissa, G. (2013), Designing Effective User Interfaces for Crowdsourcing: An Exploratory Study, ed. Sakae Yamamoto. New York: Springer.

Nandagopal, R., Arul, R. K., \& Vivek, N. (2008). Research-Methods in Business, New Delhi: Excel Books.

Palmer, S. (2011). People and Self Management. New York: Routledge.

Peng, K. Z., Hang-Yue Ngo, Junqi Shi, \& Chi-Sum Wong (2009). Gender Differences in The Work Commitment of Chinese Workers: An Investigation of Two Alternative Explanations. Journal of World Business, 44.

Penny, L. M., \& Walter, C. B. (2005). The Prediction of Contextual Performance, eds. Arne Evers, Neil Anderson, and Olga Voskuijl. Malden: Blackwell Publishing Ltd.

Petrick, J. A., \& John F. Q. (2001). "Integrity Capacity as a Strategic Asset in Achieving Organizational Excellence," Measuring Business Excellence, 5(1).

Phillips, J. M., \& Stanley, M. (2014). Gully.Human Resource Management. Mason: SouthWestern.

Pillai, R., \& Ethlyn, A. W. (2004). Transformational leadership, self-efficacy, group cohesiveness, commitment, and performance. Journal of Organizational Change Management, 17(2).

Pulakos, E. D., David W. D., \& Walter, C. B. (2003). Hiring for Knowledge-Based Competition, eds. Susan E. Jackson, Michael A. Hitt, and Angelo S. DeNisi. San Francisco: Jossey-Bass.

Purohit, S., \& Sharada, N. (2003). Enhancing Personal Effectiveness. New Delhi: Tata McGraw-Hill.

Renzulli, J. S. (2003). The Three-Ring Conception of Giftedness: Its Implications for Understanding the Nature of Innovation, ed.Larisa V. Shavinina. Oxford: Elsevier.

Resick, C.J., Jacqueline, K. M., Marcus, W. D., \& Paul, J. H. (2009). Culture, Corruption, and The Endorsement of Ethical Leadership, William H. Mobley, Ying Wang, and Ming Li. Bingley: Emerald Group Publishing Limited.

Robbins, S. P., \& Mary, C. (2012). Management. New Jersey: Pearson Education Inc.

Rumsey, M. G. (2013). The Oxford Handbook of Leadership. Oxford: Oxford University Press. https://doi.org/10.1093/oxfordhb/9780195398793.001.0001

Salari, L., \& Edoardo, D. T. (2013). "From Practice to Processes: High-Performance Work Systems and Integrity". in Wolfgang Amann dan Agata Stachowicz-Stanusch. eds. Integrity in Organizations: Building the Foundations for Humanistic Management. London: Palgrave Macmillan. 
Salas, E., Armando, X. E., \& William, B. V. (2015). Team Cohesion: Advances in Psychological Theory, Methods and Practice. Bingley: Emerald Group Publishing Ltd.

Salas, E., Rebecca, G., Ashley, M. H., \& dan, C. W. C. (2015). Measuring Team Cohesion: Observations from the Science. Human Factors Journal, 57(3).

Shields, J. (2007). Managing Employee Performance and Reward: Concepts, Practices, Strategies. Cambridge: Cambridge University Press.

Silverthorne, C. P. (2005). Organizational Psychology in Cross-Cultural Perspective. New York: New York University Press.

Simons, T. L. (1999). Behavioral Integrity as a Critical Ingredient for Transformational Leadership. Journal of Organizational Change, Management, 12(2). https://doi.org/10.1108/09534819910263640

Slocum, Jr J. W., \& Don, H. (2007). Fundamentals of Organizational Behavior. Ohio: South-Western

Sonnentag, S., \& Michael, F. (2002). Performance Concepts and Performance Theory, West Sussex: John Wiley \& Sons, Ltd.

Sperry, L. (2004). Executive Coaching: The Essential Guide for Mental Health Professionals. New York: Routledge.

Storr, L. (2004). "Leading with integrity: a qualitative research study", Journal of Health Organization and Management, 18(6). https://doi.org/10.1108/14777260410569984

Terry, L. D. (2015). Leadership Of Public Bureaucracies: The Administrator as Conservator. Oxon: Routledge.

Ugboro, I. O. (2006). "Organizational Commitment, Job Redesign, Employee Empowerment, and Intent to Quit Among Survivors of Restructuring and Downsizing”. Institute of Behavioral and Applied Management.

Umar, H. (2003). Research Method Organization Behavior. Jakarta: PT Gramedia Pustaka Utama.

Viswesvaran, C., \& Deniz S. O. (2005). Job Performance: Assessment Issues in Personnel Selection, eds. Arne Evers, Neil Anderson, and Olga Smit-Voskuijl. Malden: Blackwell Publishing Ltd.

Watkins, R., \& Doug, L. (2010). Handbook of Improving Performance in the Workplace: Selecting and Implementing Performance Interventions, San Francisco: Pfeiffer.

Weick, K. E., \& Robert, E. Q. (1999). “Organizational Change and Development”. Annual Review Psychology.

White, D. W., \& Emily, L. (2008). The Impact of Perceived Leader Integrity on Subordinates in a Work Team Environment. Journal of Business Ethics, 81. https://doi.org/10.1007/s10551-007-9546-6 
Wood, J., Rachid, Z., Michele, F., Retha, W., Rachel, M., \& Pi-Shen, S. (2013). Organizational Behaviour: Core Concepts and Applications. Milton Qld: John Wiley \& Sons, Inc.

\section{Copyright Disclaimer}

Copyright for this article is retained by the author(s), with first publication rights granted to the journal.

This is an open-access article distributed under the terms and conditions of the Creative Commons Attribution license (http://creativecommons.org/licenses/by/4.0/). 